\title{
PELAKSANAAN KECEMASAN SOSIAL DI MASA PANDEMI DI RAGUNAN JAKARTA SELATAN
}

\author{
Heni Nurhaeni $^{1 凶}$, Dinarti², Mega Khoirunnisa ${ }^{3}$ \\ Coreponding author: heni_nurhaeni@poltekkesjakarta1.ac.id \\ 123 Jurusan Keperawatan, Poltekkes Kemenkes Jakarta I, Indonesia
}

Genesis Naskah: Submitted: 03-11-2021, Revised: 08-11-2021, Accepted: 15-11-2021

\begin{abstract}
Abstrak
Masa pandemi Covid-19 merupakan masalah global yang berdampak pada perubahan status kesehatan yang dapat terjadi tidak hanya pada masalah kesehatan fisik, tetapi juga pada masalah mental dan emosional. Pandemi adalah pandemi non-bencana alam yang dapat menyebabkan krisis situasional. Hal ini dapat meningkatkan risiko berkembangnya masalah mental emosional. Tujuan kegiatan Pengabdian Masyarakat untuk mengurangi kecemasan sosial yang terjadi pada masa pandemi Covid-19. Sasaran mitra kegiatan pengabdian masyarakat adalah masyarakat dan keluarga dengan masalah kecemasan sosial di masa pandemi di wilayah Puskesmas Ragunan Jakarta Selatan. Tahapan pelaksanaan kegiatan pengabdian kepada masyarakat yaitu dengan melakukan advokasi, melakukan deteksi kecemasan menggunakan Self Reporting Questionnaire (SRQ-29), intervensi relaksasi nafas dalam, doa, dan aktivitas rutin serta pemberian poster "Cemas Sosial". Hasil pengabdian masyarakat didapatkan dari 54 warga yang terdeteksi di awal semester pertama, 22\% mengalami kecemasan, kemudian pada semester mengalami penurunan kecemasan hingga $20 \%$, dimana keluhan yang paling umum adalah mudah lelah, terganggu, dan cemas, tegang, dan khawatir. Kondisi tersebut menunjukkan bahwa di akhir masa pandemi ini, warga masih merasakan dampak psikososial. Dengan demikian, peningkatan pengetahuan serta keterampilan, pengembangan kelompok masyarakat mandiri di bidang kesehatan, dilengkapi dengan penerapan hasil penelitian kepada kegiatan Pengabdian kepada Masyarakat $(\mathrm{PkM})$, dan guna pemenuhan penanganan lanjutan perlu dilaksanakan PkM secara terpadu akan mewujudkan kesejahteraan masyarakat tangguh dan mandiri.
\end{abstract}

Kata kunci: Cemas, Self Reporting Questionaire (SRQ-29), Psikososial

\section{IMPLEMENTATION OF SOCIAL ANXIETY IN PANDEMIC PERIOD}

$$
\text { IN RAGUNAN JAKARTA SELATAN }
$$

\footnotetext{
Abstract

The Covid-19 pandemic period is a global problem that has an impact on changes in health status that can occur not only in physical health problems, but also in mental and emotional problems. A pandemic is a non-natural disaster pandemic that can lead to a situational crisis. This can increase the risk of developing mental emotional problems. The purpose of Community Service activities is to reduce social anxiety that occurs during the Covid19 pandemic. The target of community service activity partners is the community and families with social anxiety problems during the pandemic in the Ragunan Health Center, South Jakarta. The stages of implementing community service activities are by doing advocacy, detecting anxiety using the Self Reporting Questionnaire (SRQ-29), deep breathing relaxation interventions, prayer, and routine activities as well as giving "Social Anxiety" posters. The results of community service were obtained from 54 residents who were detected at the beginning of the first semester, 22\% experienced anxiety, then in the semester experienced a decrease in anxiety by up to $20 \%$, where the most common complaints were easily tired, disturbed, and anxious, tense, and worried. This condition shows that at the end of this pandemic, residents are still feeling the psychosocial impact. Thus, increasing knowledge and skills, developing independent community groups in the health sector, complemented by the application of research results to Community Service (PkM) activities, and in order to fulfill further treatment it is necessary to implement PkM in an integrated manner to realize the welfare of a resilient and independent community.
}

Keywords: Anxiety, Self Reporting Questionnaire (SRQ-29), Psychosocial 


\section{Pendahuluan}

Cemas adalah kondisi Seseorang tidak tenteram hati dikarenakan kekhawatiran atau takut (Suryani, 2015). Kondisi gelisah yang terjadi di masyarakat saat mendengar kabar wabah virus Covid-19 yang menjadi Pandemi menjadikan kondisi sosial.

Permasalahan kesehatan jiwa sangat besar dan menimbulkan beban beban kesehatan yang signifikan. Data Riskesdas tahun 2013 menunjukkan prevalensi gangguan mental emosional (gejala-gejala depresi dan ansietas) sebesar 6\% untuk usia 15 tahun ke atas. Hal ini berarti lebih dari 14 juta jiwa menderita gangguan mental emosional di Indonesia. Sedangkan untuk gangguan jiwa berat seperti gangguan psikosis, prevalensinya adalah 1,7 per 1000 penduduk. Ini berarti lebih dari 400.000 orang menderita gangguan jiwa berat (psikosis) (Kemenkes RI, 2016). Ikatan Dokter Spesialis Psikiatri menyebutkan bahwa $68 \%$ mengalami kecemasan, $67 \%$ depresi, dan $77 \%$ trauma psikologis.

Kecemasan dalam Standar Diagnosa Keperawatan Indonesia disebut sebagai Kecemasan yang merupakan kondisi emosional individu dan pengalaman subjektif terhadap objek yang tidak jelas dan spesifik akibat antisipasi bahaya yang memungkinkan individu melakukan tindakan untuk menghadapi ancaman (PPNI, 2019). Sinyal waspada yang memperingatkan individu akan bahaya dan memberikan individu kemampuan untuk bertindak dalam menghadapi ancaman (Herdman, 2019).

Kondisi ini sejalan dengan tujuan kegiatan Pengabdian Masyarakat (PkM) yang dilakukan di
Kelurahan Ragunan, Jakarta Selatan yang elah melakukan kegiatan untuk mengurangi kecemasan sosial yang terjadi di wilayah binaan Puskesmas Ragunan, Jakarta Selatan.

\section{Metode Pelaksanaan}

Pelaksanan Kegiatan Pengabdian kepada Masyarakat diharapkan tercapai sesuai dengan rencana kegiatan. Tepat sasaran yaitu Masyarakat dan Keluarga dengan masalah kecemasan sosial di masa pandemi di wilayah Puskesmas Ragunan Jakarta Selatan. Jumlah tim yang melaksanakan PkM Program Kemitraan Masyarakat sesuai dengan persyaratan yang berlaku. Adapun kegiatan yang dilaksanakan dilakukan melalui;

1. Tahap Persiapan

Tahap persiapan dimana dilaksanakannya masing-masing peran dari Poltekkes Kemenkes Jakarta 1, Kelurahan Ragunan, dan Puskesmas Ragunan Jakarta Selatan, dan masyarakat di wilayah binaan. Sehingga ada sinergisitas yang terjadi selama proses persiapan. Persiapan dilakukan dengan berbagai cara komunikasi antara pihak Poltekkes Kemenkes Jakarta 1, Dinas Kesehatan Kelurahan Ragunan, dan Puskesmas Kelurahan Ragunan Jakarta Selatan, dan masyarakat di wilayah binaan

2. Tahap Pelaksanaan kegiatan

Tahap persiapan dimana dilaksanakannya masing-masing peran dari Poltekkes Kemenkes Jakarta 1, Jajaran Kelurahan Ragunan, dan Puskesmas Kelurahan Ragunan Jakarta Selatan, dan masyarakat di wilayah binaan. 
3. Evaluasi Kinerja Program

Evaluasi kinerja program dilaksanakan sesuai masing-masing peran dari Poltekkes Kemenkes Jakarta 1, Pemerintah Kelurahan Ragunan, dan Puskesmas Ragunan Jakarta Selatan, dan masyarakat di wilayah binaan. Indikator kinerja dilakukan berdasarkan keputusan bersama maupun jika ada permintaan dari masyarakat.

Adapun indikator evaluasi kegiatan yaitu:

a. Tim Pelaksana melaksanakan program sesuai indikator output yang diseseuaikan berdasarkan keputusan bersama

b. Melaksanakan kegiatan tepat waktu sesuai rencana jadwal kegiatan

c. Pelaksanaan program memberikan manfaat dari segi kesehatan dan kepuasan masyarakat

d. Luaran PkM Program Kemitraan Masyarakat wajib maupun tambahan dapat tercapai

e. Peningkatan penerapan IPTEK di wilayah binaan Puskesmas Ragunan berupa media promosi kesehatan masalah kecemasan sosial di masa pandemi.

Sasaran kegiatan pengabdian masyarakat ini adalah Masyarakat dan Keluarga dengan masalah kecemasan sosial di masa pandemic di wilayah binaan Puskesmas Ragunan Jakarta Selatan. Kegiatan pengabdian kepada masyarakat ini sudah sesuai dengan tujuan yaitu untuk melakukan deteksi dini masalah psikososial selama pandemi dan memberikan pengetahuan tentang masalah kecemasan sosial di masa pandemi.

Lokasi kegiatan pengabdian masyarakat semester 1 dilaksanakan di di Bumi Perkemahan Ragunan dan semester 2 di rumah Kader Kesehatan RW 05 dan 08 di wilayah binaan Puskesmas Kelurahan Ragunan Jakarta Selatan. Sasaran kegiatan pengabdian masyarakat ini adalah Masyarakat dan Keluarga dengan masalah kecemasan sosial di masa pandemi.

Kegiatan deteksi menggunakan Self Reporting Questionnaire (SRQ-29) (Kemenkes RI, 2020) dan mengikuti protokol Protokol Dukungan Kesehatan Jiwa dan Psikosial (DKJPS) dilaksanakan, Tim PkM akan menganalisis data dengan program excell, warga dibekali dengan "Poster Cemas Sosial" dan thematic literatur riview (Nursalam, 2020).

\section{Hasil dan Pembahasan}

Pada awal pertemuan, tim mengidentifikasi masyarakat yang beresiko mengalami Kecemasan social di Masa Pandemi dengan pengisian kuesioner Self Reposting Quesionaire (SRQ-29) kepada kader dan masyarakat. Setelah itu masyarakat mengikuti penatalaksaan kecemasan sosial yang difasilitasi oleh tim dan mahasiswa selanjutnya diberikan intervensi relaksasi nafas dalam sebagai penguatan intervensi mandiri. Kemudian evaluasi dilakukan oleh tim dengan melakukan pengukuran Nilai SRQ-29 pada masing-masing peserta kegiatan. 
Kegiatan PkM yang dilaksanakan selama 8 bulan dengan 6 kali pertemuan di wilayah Kelurahan Ragunan ditemui hasil, sebagai berikut:

Tabel 1. Distribusi Karakteristik Responden Berdasarkan jenis kelamin dan hasil SRQ

\begin{tabular}{|c|c|c|c|c|c|c|}
\hline \multirow[t]{2}{*}{ Variabel } & \multirow{2}{*}{$\frac{\text { Semester I }}{\mathrm{N}}$} & \multicolumn{3}{|c|}{ Semester II } & \multicolumn{2}{|c|}{ Total } \\
\hline & & $\%$ & $\mathrm{~N}$ & $\%$ & $\mathrm{~N}$ & $\%$ \\
\hline \multicolumn{7}{|l|}{ Jenis Kelamin: } \\
\hline 1. Laki-laki & 27 & 50 & 27 & 50 & 54 & 50 \\
\hline 2. Perempuan & 27 & 50 & 27 & 50 & 54 & 50 \\
\hline \multicolumn{7}{|l|}{ Hasil deteksi SRQ: } \\
\hline 1. Sakit Kepala & 2 & 8,7 & 2 & 13,3 & 4 & 10,5 \\
\hline 2. Tangan gemetar & 1 & 4,35 & 1 & 6,7 & 2 & 5,3 \\
\hline 3. Pikiran terganggu & 4 & 17,39 & 0 & 0 & 4 & 10,5 \\
\hline $\begin{array}{l}\text { 4. Sulit mengekspresikan } \\
\text { perasaan }\end{array}$ & 1 & 4,35 & 0 & 0 & 1 & 2,6 \\
\hline 5. Tidur tidak terlelap & 2 & 8,7 & 1 & 6,7 & 3 & 7,9 \\
\hline $\begin{array}{l}\text { 6. Cemas, tegang, } \\
\text { khawatir }\end{array}$ & 2 & 8,7 & 2 & 13,3 & 4 & 10,5 \\
\hline $\begin{array}{l}\text { 7. Minat berteman } \\
\text { berkurang }\end{array}$ & 1 & 4,35 & 0 & 0 & 1 & 2,6 \\
\hline 8. Tidak nafsu makan & 1 & 4,35 & 0 & 0 & 1 & 2,6 \\
\hline 9. Merasa tidak berharga & 1 & 4,35 & 1 & 6,7 & 2 & 5,3 \\
\hline $\begin{array}{l}\text { 10.Memiliki pikiran untuk } \\
\text { mengakhiri hidup }\end{array}$ & 1 & 4,35 & 0 & 0 & 1 & 2,6 \\
\hline 11.Mudah Lelah & 2 & 8,7 & 3 & 20 & 5 & 13,2 \\
\hline $\begin{array}{l}\text { 12.Tidak enak di perut/ } \\
\text { Gangguan pencernaan }\end{array}$ & 2 & 8,7 & 1 & 6,7 & 3 & 7,9 \\
\hline $\begin{array}{l}\text { 13. Minum } \\
\text { Alkohol/narkoba/ } \\
\text { merokok }\end{array}$ & 2 & 8,7 & 2 & 13,3 & 4 & 10,5 \\
\hline $\begin{array}{l}\text { 14. Takut dan } \\
\text { merasa terganggu } \\
\text { dengan Pandemi }\end{array}$ & 1 & 4,35 & 2 & 13,4 & 3 & 7,9 \\
\hline
\end{tabular}

Hasil analisis menunjukkan bahwa Karakteristik Warga yang mengikuti kegiatan PkM di wilayah binaan Puskesmas Ragunan Jakarta Selatan adalah berjenis kelamin Laki-laki dan Perempuan, dan hasil deteksi warga pada semester 1 dan 2 sebagai berikut perbaikan pikiran terganggu, tidur lebih nyenyak, memiliki minat untuk berteman, nafsu makan meningkat, tidak memiliki pikiran untuk mengakhiri hidup, perbaikan di sistem pencernaan. Dan terjadi peningkatan pada keluhan mudah Lelah dan takut serta merasa terganggu dengan Pandemi.

\section{Kesimpulan dan Saran}

Pengabdian Masyarakat (PkM) yang dilakukan kepada 54 Warga di Kelurahan Ragunan, Jakarta Selatan yang telah melakukan kegiatan dapat mengurangi kecemasan sosial yang terjadi di wilayah binaan Puskesmas Ragunan, Jakarta Selatan.

Pengabdian kepada Masyarakat Skema Program Kemitraan Masyarakat (PKM) merupakan bentuk sinergi Poltekkes Kemenkes dengan Puskesmas Ragunan. Kegiatan ini dilakukan dengan menerapkan IPTEKS kepada 
masyarakat untuk meningkatkan ilmu pengetahuan dan keterampilan di bidang Kesehatan, membentuk dan mengembangkan kelompok masyarakat yang mandiri di bidang Kesehatan, serta mengaplikasikan hasil riset Tim di tahun 2019 untuk meningkatan kesehatan masyarakat agar terwujud kesejahteraan masyarakat. Selain itu kegiatan ini dapat menemukan solusi atas persoalan yang dihadapi masyarakat di wilayah binaan Puskesmas Ragunan serta secara langsung atau tidak langsung yang berpotensi mempengaruhi kenyamanan kehidupan masyarakat.

\section{Daftar Pustaka}

Herdman, T. H. (2019). Nanda International Inc. Diagnosis Keperawatan: Defenisi \& Klasifikasi 2015-2017. EGC.

Kemenkes RI. (2016). Program Indonesia Sehat Dengan Pendekatan Keluarga. In Kementerian Kesehatan RI. Jakarta: Kementerian Kesehatan RI.

Kemenkes RI. (2020). Protokol Layanan DKJPS Anak dan Remaja Pda Masa Adaptasi Kebiasaan Baru Pandemi covid-19. Jakarta.

Nursalam. (2020). Literature Systematic Review pada Pendididikan Kesehatan. Surabaya. Indonesia: Universitas Airelangga.

PPNI. (2019). Standar Diagnosis Keperawatan Indonesia: Definisi dan Indikator Diagnostik. EGC.

Suryani, S. (2015). Mengenal gejala dan penyebab gangguan jiwa. Stigma Terhadap Orang Gangguan Jiwa, (October 2013), 1-12. 